\title{
Effects of Seasonality on Physico-Chemical Properties and Selected Ligands on Rivers in Sigor Division, West Pokot County, Kenya
}

\author{
Nyasimi Ayora Gershom ${ }^{1}$, Stella Kirui ${ }^{2^{*}}$, John Maingi ${ }^{1}$, Anthony Kebira ${ }^{1}$
}

\author{
${ }^{1}$ Kenyatta University, Department of Biochemistry, Microbiology and Biotechnology, Nairobi. KENYA \\ ${ }^{2}$ Maasai Mara University, Biological Science Department, Narok, KENYA \\ *Corresponding Author: kiruistella@mmarau.ac.ke
}

Citation: Gershom, N. A., Kirui, S., Maingi, J., \& Kebira, A. (2019). Effects of Seasonality on Physico-Chemical Properties and Selected Ligands on Rivers in Sigor Division, West Pokot County, Kenya. Aquademia, 3(1), ep19012. https://doi.org/10.29333/aquademia/8393

\begin{abstract}
ARTICLE INFO
Received: 29 May 2019

Accepted: 29 Jun. 2019

ABSTRACT

There is need to determine the exact nature of river systems for key decisions such as water treatment, construction of irrigation dams, piping systems or bridges to be made. Seasonality affects the nature and amounts of compounds getting into or out of rivers. It is therefore critical to know the exact amounts of physico-chemicals and ligands in water systems. This study aimed at analyzing the levels of various physico-chemicals and ligands in the rivers of Sigor division, West Pokot county, Kenya during different seasons. Sampling was done at four different parts of the four rivers (Weiwei, Chesogon, Lomut and Muruny) during both the wet and dry seasons. Analysis was then conducted, in situ for most physico-chemicals and later on by UV-VIS spectroscopy for the ligands. The findings revealed that there was a great impact of seasonality on most of the physico-chemical parameters analyzed. Crucial parameters such as $\mathrm{pH}$, temperature, conductivity and turbidity were all affected by seasonality. The rivers did not however differ significantly in most of the physico-chemical parameters. Muruny river, however experienced more values of physico-chemical parameters due to its agricultural neighborhood. The phosphate values in the rivers were way above the permissible values. However, nitrate values were within the recommended values whereas sulfate values in the rivers were below the threshold values.
\end{abstract}

Keywords: water, physico-chemicals, ligands, West Pokot County

\section{BACKGROUND}

Clean water is a very scarce resource especially in developing nations. Sigor division in West Pokot county, Kenya contain vast dry regions. Her inhabitants are nomadic pastoralists and small-scale farmers. Water for animal and human consumption is derived primarily from four rivers that originate from Cherengany hills, in the nearby Trans Nzoia county. The rivers are River Chesogon, Weiwei, Lomut and Muruny. They latter on merge after downwards to form the great Tukwel river. The regions enjoy two major seasons in a year i.e the wet and dry season. During the dry season, the pastoralists move seeking pasture. Due to strong winds and loose soil structure experienced in dry seasons, many particulates end up in the rivers. In the wet seasons, there is an increase in discharge into the rivers from poor sewage systems and agricultural runoffs. These particulates contain chemical and bio-chemical compounds that affect the physicochemical properties of the rivers (Aniyikaiye et al., 2019).
Several compounds (mostly inorganic) affect the physicochemical nature of water. The total solids (TS), whether dissolved or suspended are attributed to solid particulates such as from dust and agrochemicals. Most of the dissolved solids are inorganic and quite ionizable. Therefore, together with other parameters such as $\mathrm{pH}$ and temperature, they affect water electric conductivity. Electrical conductivity is therefore a function of dissolved solids (Butler and Ford, 2018). High water electrical conductivity implies a lot of chemical pollution and such water is unfit for human consumption. Variation of $\mathrm{pH}$ also determine the solubility of organic and inorganic complexes in water (National Research Council (US) safe drinking water committee, 1977). The recommended $\mathrm{pH}$ value for clean potable water is between 6.5-8.0. However, this might not be the case in a polluted water system such as rivers. Extreme $\mathrm{pH}$ values affect growth of aquatic life and corrode water pipes (Kumar and Puri, 2012). Extreme pH values mobilize toxic heavy metals such as lead compounds which have severe effects to humans. Water with more dissolved solids has a higher density minimizing its portability. 


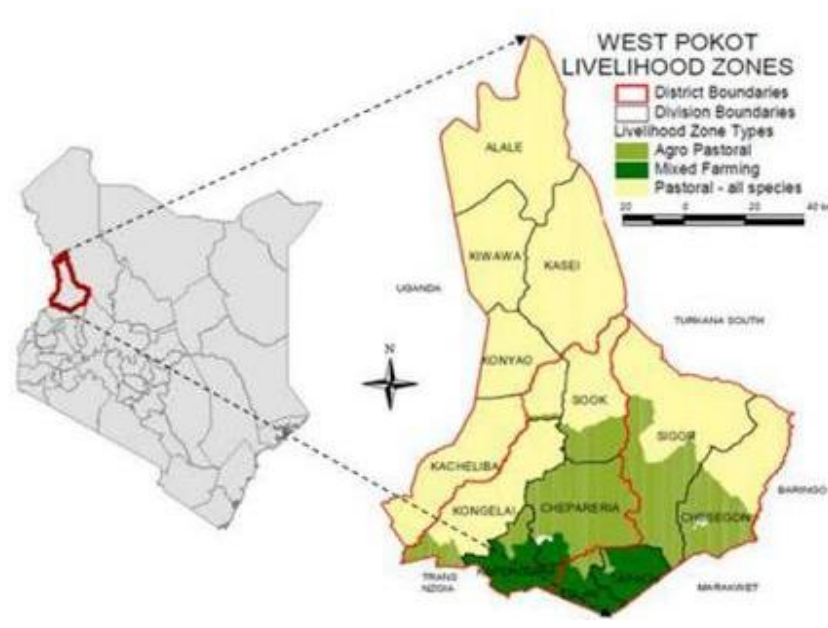

(a)

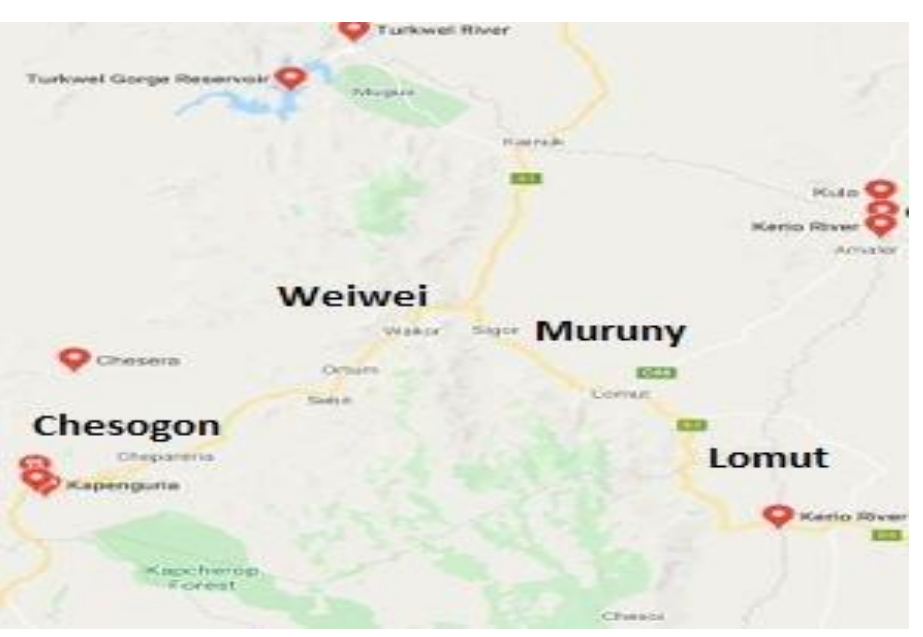

(b)

Figure 1. Map of West Pokot county in Kenya (a) Sigor division showing the locations of the rivers (b)

Most of the suspended solids affect water turbidity. This has a toll on other parameters such as visibility and flow rate. Poor water visibility reduces the intensity of sunlight reaching planktons, essential for aquatic life. Poor water visibility also minimize navigation in the rivers for fear of unforeseen hazards. The flow rate of water is key for modelling of several socio-economic factors such as where best to tap water for piping purposes or build a dam for irrigation. Water with a high flow rate distribute any pollutants present over a wider surface, owing to its fast velocity. High turbidity also offers more surface area for attachment of pathogens in water (Chahal et al., 2016).

Water should be well aerated (around 6\%) in an unpolluted water system (Kumar and Puri, 2012). Dissolved oxygen values in water are very critical for sustenance of aquatic life and human/animal consumption. Water alkalinity determines the ability of the water to buffer itself against extreme acidic conditions. This is very crucial for the survival of aquatic life and for human/animal consumption. Low alkalinity values can result due to acid rain into the system. Excessive alkalinity values resulting from fecal discharge by animals or humans affect the availability of other water minerals and ligands such as nitrates, sulfates, chlorides and phosphates. Abundance of these ligands in river systems above permissible limits is an indicator of polluted water.

Variation of seasons lead to different quantities of physicochemicals in rivers. During the dry seasons, there is less precipitation and higher temperature values leading to more evaporation of the little water present in the rivers. The solid particulates are also increased owing to stronger winds. Irradiation in the water systems is also increased due to higher sunlight intensities. During wet seasons, there is more precipitation and lower temperature. The water capacity is thus more. On the other hand, there is less sunlight irradiation and little particulates resulting from dust get into rivers. However, most sewerages are full and there are more agrochemical residues leaching into the rivers. It is thus very difficult to know the exact position of river systems as far as physico-chemicals are concerned unless analysis is done during both seasons.
This study aimed at analyzing the levels of physicochemicals in four rivers of Sigor division, West Pokot county during wet and dry seasons. The amounts of these compounds and parameters are essential in informing relevant authorities on the right decisions to make at the appropriate time. Crucial factors such as the exact point to construct a bridge or dam, where to tap water for piping and materials to use as well as choice of chemicals to use for water softening or to kill pathogens are all based on such decisions.

\section{MATERIALS AND METHODS}

\section{Study Area}

The research was conducted in Sigor division, West Pokot county, Kenya (between latitude $1.1359^{\circ} \mathrm{N}$ and longitude $\left.35.7121^{\circ} \mathrm{E}\right)$. Samples were taken from four different points of the rivers $\left(\mathrm{P}_{1}, \mathrm{P}_{2}, \mathrm{P}_{3}\right.$ and $\mathrm{P}_{4}$ with $\mathrm{P}_{1}$ being the river mouth and cascading down to the other points). Lomut river was an estuary to Muruny river while Chesogon river was the main feeder for River Weiwei. The two rivers then merge together with other rivers to form the great Tukwel river. Figure 1 illustrates the four rivers and regions that were sampled.

\section{Sample Collection}

Samples were collected from 4 locations located immediately upstream and at least $100 \mathrm{~m}$ downstream. This was done four times over a period of eight months as from January to September 2013 which spanned through the dry season (January 2013 - March 2013) and the rainy season (April 2013 - June 2013) to cater for seasonal variations. Samples at the different courses of a particular river were used to make a composite sample. A total of 32 samples were collected during the sampling period with each point sampled four times. The sample size for the study was determined using Fisher formula with a confidence level of $95 \%$ with a margin error of $5 \%$ (Fisher, 1998).

$$
n=\frac{Z^{2} P q D}{d^{2}}
$$

Where; $\mathrm{n}=$ sample size, $\mathrm{p}=$ anticipated prevalence which was $3 \%(0.03)$ in this study, $q=$ failure which was calculated as 
(100\% - 3\%) giving 97\% (0.97), $\mathrm{Z}=$ is the appropriate value from a normal distribution for the desired confidence level which was 1.96 in this study, $d=$ allowable error $(0.086)$ and $D$ $=$ design effect which was given a value of 2 because replication was carried out based on 3\% prevalence and $\mathrm{Z}$ value of 1.96 . A final sample size of 30 samples was finally obtained.

\section{Data Collection and Analysis}

Some of the physico-chemical measurements were taken in situ at the sampling point whereas others required analysis in the lab. These samples were properly packed in sterile $500 \mathrm{ml}$ polypropylene bottles. $1 \%$ nitric acid and formaldehyde solution was added to the samples whose tests don't interfere with these solutions. They were then transported to Kenyatta University Microbiology Laboratory for analysis. The maximum storage duration before analysis was 48 hours for all the samples transported to the lab.

Water temperature $\left({ }^{\circ} \mathrm{C}\right), \mathrm{pH}$, dissolved oxygen $(\mathrm{mg} / \mathrm{L})$, turbidity and conductivity were measured in situ using Universal Multiline P4 WTW (Wilheim, Germany). Electrical conductivity was measured using a conductivity probe expressed in Micro Siemens per centimeter $\left(\mu \mathrm{Scm}^{-1}\right)$ and turbidity was recorded in Nephelometer Turbidity Units (NTU).

The ligands; phosphates, sulfates and nitrates were determined using UV VIS (Jenway 6850) analysis as outlined below.

Phosphates: A conditioning reagent was made by dissolving $1.7081 \mathrm{~g}$ of ammonium molybdate and ascorbic acid $(5.82 \mathrm{~g} / 300 \mathrm{ml}$ distilled water) in $150 \mathrm{ml}$ warm water. The solution was cooled before diluting to $250 \mathrm{ml}$. $0.125 \mathrm{~g}$ of hydrazine sulphate in $100 \mathrm{ml}$ distilled water was added. Analyte samples were diluted by a factor of 10 and added the conditioning reagent before measuring the absorbances at 830-860 nm against those of the blank and standards.

Nitrates: Nitrate standards were prepared by dissolving $8.0 \mathrm{~g}$ of salicyclic acid in $100 \mathrm{ml}$ of $1 \mathrm{M} \mathrm{H}_{2} \mathrm{SO}_{4}$ acid then swirling to fully dissolve. $10 \mathrm{ml}$ of this solution was added to $90 \mathrm{ml}$ of aliquot sample solution. Acidification using $1 \mathrm{M} \mathrm{HCl}$ was done to minimize interference by other ligands. Absorbance was checked in the range of $270-320 \mathrm{~nm}$ against those of the blank and standards.

Sulfates: For standard preparation, $10 \mathrm{~g}$ of $\mathrm{NaCl}$ and $10 \mathrm{ml}$ of conc $\mathrm{HCl}$ acid were added to $40 \mathrm{ml}$ of glycerol solution. A yellowish color was formed. $5 \mathrm{ml}$ of this solution was added to $45 \mathrm{ml}$ of analyte solution and the absorbance read at 410 $430 \mathrm{~nm}$ against those of the blank and standards.

\section{Statistical Analysis}

95\% level of confidence was used for all the statistical analyses done. Ms Excel (version 2016) and OriginLab (version 6.5) statistical softwares were used.

\section{RESULTS AND DISCUSSIONS}

\section{Physico-chemical Parameters in the Rivers}

All the rivers had alkaline water with Muruny river having the most basic water (8.17 in the wet and 9.20 during the dry season). The high alkalinity values in the rivers can be traced down to contaminants such as soaps and detergents as well as agricultural pesticides (National Research Council, 1998). Muruny river is located in an agricultural zone, therefore susceptible to most of these basic agrochemicals that increase the $\mathrm{pH}$ of its water. On contrary, Chesogon river located in a pastoralist region had the lowest $\mathrm{pH}$ values indicating less entrance of these compounds. The samples analyzed during the dry season had a higher $\mathrm{pH}$ than those analyzed during the wet season. During the wet seasons, there is more precipitation and the rivers have more water. The compounds leading to production of a basic environment in the water are thus diluted by a higher factor leading to a lower $\mathrm{pH}$ value. Another factor leading to lower $\mathrm{pH}$ values in the rivers in the wet season is influx of acidic compounds into the rivers during this period. For example, acid rains have a low $\mathrm{pH}$ value and when it precipitates into the river, they definitely lower the $\mathrm{pH}$ of this water. While very acidic water (below pH 5.0) is bad for farming, very basic water (above $\mathrm{pH}$ 9.0) is bad for construction. The optimal $\mathrm{pH}$ range for coliforms and other bacteria is 6.5-8.5 (Halage et al., 2015). Therefore, all the rivers were prone to these pathogens.

There was a similar trend in the temperature levels of the rivers with Muruny river also having the highest average temperature. Temperature is a physical and very dynamic environmental parameter that depends on other factors. Ambient conditions such as sunlight intensity are key in determining the temperature of water in a river. Shallow rivers are affected more than deep ones. In this region, there was no significant difference in sunlight intensity based on the residents' perception. There was no significant difference in the temperature of different river points. Change in temperature affects the chemical and biochemical compounds as well as influence other physico-chemical parameters in the river. At higher temperature systems, critical parameters such as dissolved oxygen, crucial for aquatic life reduce. Several bacteria and coliforms such as E. coli, V. cholerae, Salmonella and Shigella species as well as Fecal streptococci thrive well at high temperatures $\left(35-45^{\circ} \mathrm{C}\right)$ (Scott et al., 2002). These pathogens have a lower tolerance to low temperature thus, the cooler the water, the safer it is.

Electrical conductivity values in the rivers were significantly high during the dry season compared to the wet season $(\mathrm{P}>0.05)$. There was no significant deviation in electrical conductivity values across the rivers at different points. Several factors can be drawn for these findings, key amongst them the correlation between electrical conductivity and other physico-chemical properties such as temperature, $\mathrm{pH}$ and turbidity. High temperature increases the ionization of compounds in water leading to a higher electrical conductivity (Brini et al., 2017). pH also affects the immobilization of complex compounds affecting their conductivity. During the dry season, there is less precipitation and movement of water. The ions in rivers thus have a higher concentration and are more still, enabling them to be detected thus leading to higher electrical conductivity values. Chesogon river $(192.75 \pm 2.06$ $\mu \mathrm{Scm}^{-1}$ during the wet season and $221.83 \pm 2.51 \mu \mathrm{Scm}^{-1}$ during the dry season) and Muruny rivers (163.00 $\pm 6.22 \mu \mathrm{Scm}^{-1}$ during the wet season and $194.50 \pm 13.89 \mu \mathrm{Scm}^{-1}$ during the dry season) had the highest levels of electrical conductivity. The high level of conductivity in Chesogon river can be attributed to low 
Table 1. Physico-chemical properties of rivers in the study area

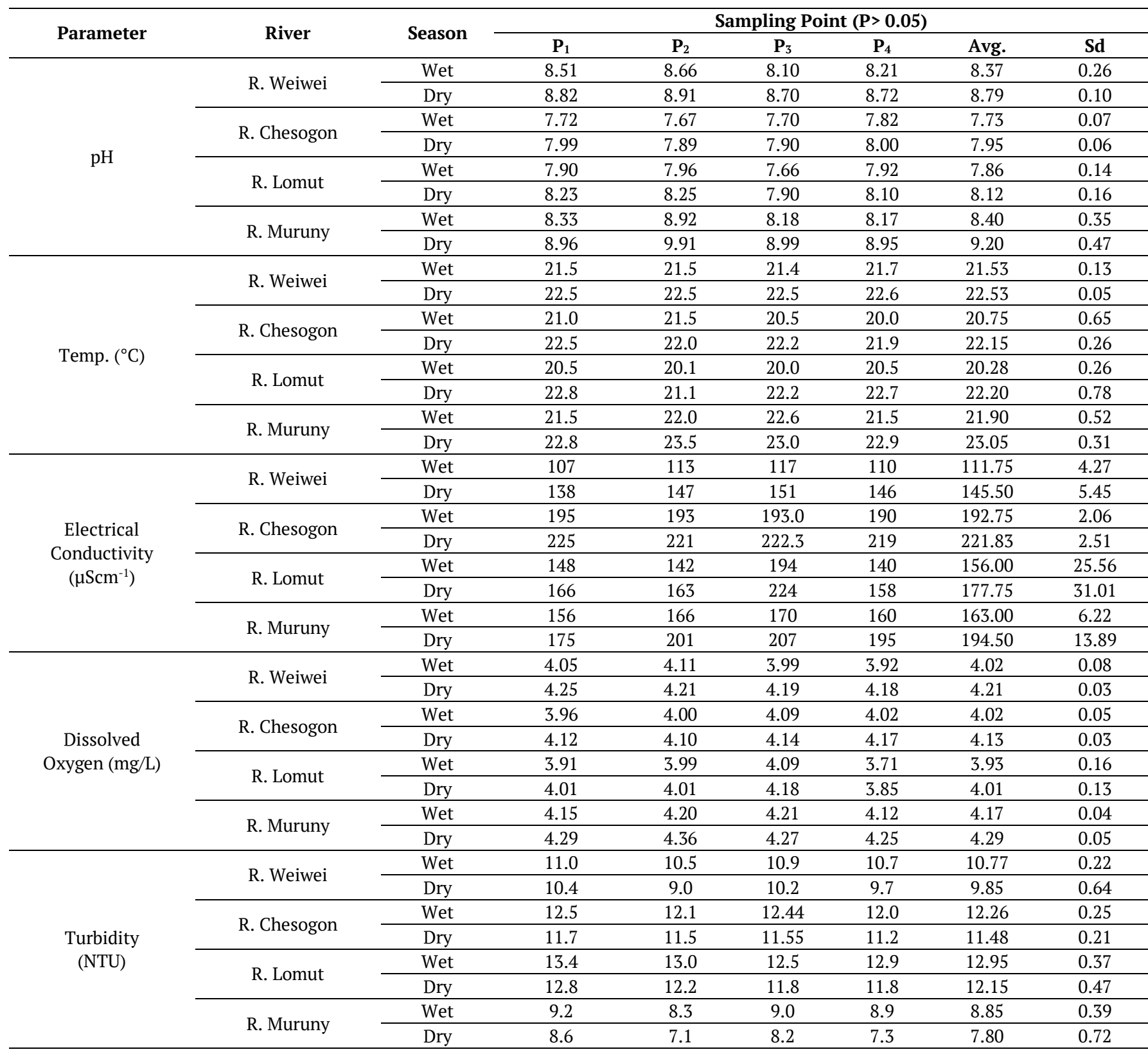

water volumes in the region resulting from its more arid nature. On the other hand, Muruny river gets more influx of agrochemicals and other pollutants such as soaps and detergents from the local residents. These compounds are quite soluble in water leading to high electrical conductivity (Savjani et al., 2012). Weiwei and Lomut rivers receive more sewer discharge which contain more microorganisms than chemical compounds. The microorganisms are less soluble and do not greatly impart the conductivity. The electrical conductivity values of the rivers were within the permissible WHO limits of clean water $\left(150-500 \mu \mathrm{Scm}^{-1}\right)$. Table 1 summarizes the physico-chemical parameters of the rivers in Sigor division.

Dissolved oxygen is a crucial parameter of rivers as it is very key in survival of aquatic life. The permissible dissolved oxygen values in clean river water range $5-6 \mathrm{mg} / \mathrm{L}$ for warm biota and 6.5 to $9.5 \mathrm{mg} / \mathrm{L}$ for cold biota (WHO, 1996). All the rivers in the study region were found to have insufficient dissolved oxygen values for survival of fish and human and animal consumption during all seasons. Muruny river had the most appreciable values of dissolved oxygen compared to the other rivers $(4.17 \pm 0.04 \mathrm{mg} / \mathrm{L}$ in wet season and $4.29 \pm 0.05 \mathrm{mg} / \mathrm{L}$ in the dry season). Seasonality of the rivers did not affect the amount of dissolved oxygen. There was also no clear disparity in levels of dissolved oxygen across the rivers in either season. Several coliforms are facultative anaerobs and thrive well in limited amount of dissolved oxygen (Cabral, 2010). Therefore, reduction in oxygen levels in the rivers promote growth of these harmful microorganisms.

The turbidity values in the rivers were high during the wet season compared to the dry season. This is due to the increased discharge of materials into the rivers during wet seasons. Water movement during wet seasons is also quite higher leading to erosion of the river walls and thus adding more particulates (silts and sediments) that increase turbidity. The turbidity levels of the rivers were above the permissible limits of 10 NTU in clean rivers except for Muruny and River Weiwei during the dry season (Guidelines for Drinking-Water Quality: 
Table 2. Levels of selected ligands in the study area

\begin{tabular}{|c|c|c|c|c|c|c|c|c|}
\hline \multirow{2}{*}{ Ligand } & \multirow{2}{*}{ River } & \multirow{2}{*}{ Season } & \multicolumn{6}{|c|}{ Sampling Point $(P>0.05)$} \\
\hline & & & $\mathbf{P}_{1}$ & $\mathbf{P}_{2}$ & $\mathbf{P}_{3}$ & $\mathbf{P}_{4}$ & Avg. & Sd. \\
\hline \multirow{8}{*}{$\begin{array}{l}\text { Phosphates } \\
\text { (mg/L) }\end{array}$} & \multirow{2}{*}{ R. Weiwei } & Dry & 0.53 & 0.55 & 0.56 & 0.57 & 0.55 & 0.02 \\
\hline & & Wet & 0.51 & 0.51 & 0.52 & 0.52 & 0.52 & 0.01 \\
\hline & \multirow{2}{*}{ R. Chesogon } & Dry & 0.44 & 0.45 & 0.46 & 0.55 & 0.48 & 0.05 \\
\hline & & Wet & 0.42 & 0.41 & 0.42 & 0.50 & 0.44 & 0.04 \\
\hline & \multirow{2}{*}{ R. Lomut } & Dry & 0.56 & 0.57 & 0.58 & 0.59 & 0.58 & 0.01 \\
\hline & & Wet & 0.52 & 0.51 & 0.52 & 0.54 & 0.52 & 0.01 \\
\hline & \multirow{2}{*}{ R. Muruny } & Dry & 0.59 & 0.55 & 0.50 & 0.60 & 0.56 & 0.05 \\
\hline & & Wet & 0.57 & 0.54 & 0.55 & 0.56 & 0.56 & 0.01 \\
\hline \multirow{8}{*}{$\begin{array}{l}\text { Sulfates } \\
(\mathrm{mg} / \mathrm{L})\end{array}$} & \multirow{2}{*}{ R. Weiwei } & Dry & 15.00 & 16.00 & 17.00 & 13.00 & 15.25 & 1.71 \\
\hline & & Wet & 13.00 & 14.00 & 15.00 & 10.00 & 13.00 & 2.16 \\
\hline & \multirow{2}{*}{ R. Chesogon } & Dry & 13.00 & 14.00 & 15.00 & 12.00 & 13.50 & 1.29 \\
\hline & & Wet & 11.00 & 12.00 & 13.00 & 10.00 & 11.50 & 1.29 \\
\hline & \multirow{2}{*}{ R. Lomut } & Dry & 16.00 & 17.00 & 18.00 & 15.00 & 16.50 & 1.29 \\
\hline & & Wet & 14.00 & 15.00 & 16.00 & 13.00 & 14.50 & 1.29 \\
\hline & \multirow{2}{*}{ R. Muruny } & Dry & 17.00 & 18.00 & 19.00 & 17.00 & 17.75 & 0.96 \\
\hline & & Wet & 15.00 & 15.00 & 16.00 & 15.00 & 15.25 & 0.50 \\
\hline \multirow{8}{*}{$\begin{array}{l}\text { Nitrates } \\
(\mathrm{mg} / \mathrm{L})\end{array}$} & \multirow{2}{*}{ R. Weiwei } & Dry & 32.00 & 35.00 & 36.00 & 33.00 & 34.00 & 1.83 \\
\hline & & Wet & 29.00 & 31.00 & 32.00 & 31.00 & 30.75 & 1.26 \\
\hline & \multirow{2}{*}{ R. Chesogon } & Dry & 28.00 & 31.00 & 32.00 & 32.00 & 30.75 & 1.89 \\
\hline & & Wet & 26.00 & 26.00 & 27.00 & 30.00 & 27.25 & 1.89 \\
\hline & \multirow{2}{*}{ R. Lomut } & Dry & 34.00 & 37.00 & 38.00 & 35.00 & 36.00 & 1.83 \\
\hline & & Wet & 30.00 & 32.00 & 33.00 & 33.00 & 32.00 & 1.41 \\
\hline & \multirow{2}{*}{ R. Muruny } & Dry & 35.00 & 39.00 & 40.00 & 37.00 & 37.75 & 2.22 \\
\hline & & Wet & 33.00 & 36.00 & 37.00 & 35.00 & 35.25 & 1.71 \\
\hline
\end{tabular}

Fourth Edition Incorporating the First Addendum. Geneva: World Health Organization; 2017). Lomut river had the highest turbidity levels $(12.95 \pm 0.37 \mathrm{NTU}$ during the wet season and $12.15 \pm 0.47 \mathrm{NTU}$ during the dry season). High water turbidity affects locomoture in the rivers as well as minimizing the intensity of sunlight radiations entering the river. High turbidity has also been associated with providing attachment sites for water pathogens such as bacteria and coliforms.

\section{Ligand Analysis in the Rivers}

All the rivers in the study region had higher phosphate values to the recommended one $(0.03 \mathrm{mg} / \mathrm{L})$. This imply that there was a lot of pollution leading to these high values. River Chesogon had significantly lower phosphates in her water during both dry and wet seasons $(0.48 \pm 0.05 \mathrm{mg} / \mathrm{L}$ and $0.44 \pm 0.04 \mathrm{mg} / \mathrm{L}$ respectively). Chesogon river enjoys the least human population around and thus the fewest anthropogenic pollution. The highest phosphate values were reported in Muruny river, where there is more agricultural practice. Phosphates are a key part of essential nutrients (ideally as elemental phosphorus or frequently as ammonium phosphate fertilizers) (Sharma et al., 2013). These compounds are also quite soluble in water and quickly leach into rivers. Phosphates can also be supplied from sewer discharge, explaining the high amounts of this contaminants by rivers Weiwei and Lomut, which enjoy more human population around them. Phosphates enrich algae population thus increasing the risk of their existence as well as other pathogens. Table 2 summarizes the levels of phosphates, sulfates and nitrates in the sample area.

The sulfate levels in all the rivers were higher during the dry season compared to the wet season. Sulfates, exist as ions together with other metals or compounds. During wet seasons, there is more water levels and thus the dilution factor is high. During dry seasons there is less water and thus the concentration of sulfates is more. The sulfate levels in all the samples analyzed were well below the limits of $250 \mathrm{mg} / \mathrm{L}$ (Nkansah et al., 2010). Therefore, the water of all the rivers were safe for consumption as far as sulfates are concerned. The same observation was observed for nitrates which had vales ranging between $27.25 \pm 1.89 \mathrm{mg} / \mathrm{L}$ to $37.75 \pm 2.22 \mathrm{mg} / \mathrm{L}$. These values were within the given permissible range of 20 to $60 \mathrm{ppm}$ $(\mathrm{mg} / \mathrm{L})$ for safe river water. Both sulfates and nitrates find their way into rivers through agricultural chemicals and sewer wastewaters. It can thus be noted that the residents of Sigor division do not over-utilize fertilizers with nitrate and sulfate ligands.

\section{CONCLUSIONS}

Seasonality affected the levels of several physico-chemical properties. However, there were no major deviations in physico-chemical properties between different river positions in the study area. All the rivers had low temperature values of about $20.5-22.5^{\circ} \mathrm{C}$ and were quite alkaline in nature. The electrical conductivities of the rivers were way above the recommended guidelines while dissolved oxygen was below the threshold $5 \mathrm{mg} / \mathrm{L}$. The rivers experienced high turbidity values especially during the wet seasons. All the rivers had excessive phosphates values during all the seasons. The levels of sulfates were below the recommended threshold while nitrate levels were in the recommended range of clean water. 


\section{ACKNOWLEDGEMENTS}

The authors wish to acknowledge all the research assistants involved in guiding the researchers and data collection (sampling) in Sigor division. The authors are also thankful to the staff at Kenyatta university Microbiology lab. For their assistance in characterization.

\section{REFERENCES}

Aniyikaiye, T. E., Oluseyi, T., Odiyo, J. O., \& Edokpayi, J. N. (2019). Physico-Chemical Analysis of Wastewater Discharge from Selected Paint Industries in Lagos, Nigeria. International journal of environmental research and public health, 16(7), $1235 . \quad$ https://doi.org/10.3390/ ijerph16071235

Butler, B. A., \& Ford, R. G. (2018). Evaluating relationships between total dissolved solids (TDS) and total suspended solids (TSS) in a mining-influenced watershed. Mine water and the environment, 37(1), 18-30. https://doi.org/ 10.1007/s10230-017-0484-y

National Research Council (US) Safe Drinking Water Committee. Drinking Water and Health: Volume 1. Washington (DC): National Academies Press (US); 1977. V, Inorganic Solutes. Retrieved from https://www.ncbi.nlm. nih.gov/books/NBK234170/

Kumar, M., \& Puri, A. (2012). A review of permissible limits of drinking water. Indian journal of occupational and environmental medicine, 16(1), 40-44. https://doi.org/ 10.4103/0019-5278.99696

Chahal, C., van den Akker, B., Young, F., Franco, C., Blackbeard, J., \& Monis, P. (2016). Pathogen and Particle Associations in Wastewater: Significance and Implications for Treatment and Disinfection Processes. Advances in applied microbiology, 97, 63-119. https://doi.org/10.1016/ bs.aambs.2016.08.001

Fisher, L. D. (1998). Self - designing clinical trials. Statistics in medicine, 17(14), 1551-1562. https://doi.org/10.1002/(SICI) 1097-0258(19980730)

National Research Council (US) Committee to Evaluate the Viability of Augmenting Potable Water Supplies with Reclaimed Water. Issues in Potable Reuse: The Viability of Augmenting Drinking Water Supplies With Reclaimed Water. Washington (DC): National Academies Press (US); 1998. 2, Chemical Contaminants in Reuse Systems. Retrieved from https:/www.ncbi.nlm.nih.gov/books/NBK230185/
Halage, A. A., Ssemugabo, C., Ssemwanga, D. K., Musoke, D., Mugambe, R. K., Guwatudde, D., \& Ssempebwa, J. C. (2015). Bacteriological and physical quality of locally packaged drinking water in Kampala, Uganda. Journal of environmental and public health, 2015, 942928. https://doi.org/10.1155/2015/942928

Scott, T. M., Rose, J. B., Jenkins, T. M., Farrah, S. R., \& Lukasik, J. (2002). Microbial source tracking: current methodology and future directions. Applied and environmental microbiology, 68(12), 5796-5803. https://doi.org/10.1128/ aem.68.12.5796-5803.2002

Brini, E., Fennell, C. J., Fernandez-Serra, M., Hribar-Lee, B., Lukšič, M., \& Dill, K. A. (2017). How Water's Properties Are Encoded in Its Molecular Structure and Energies. Chemical reviews, 117(19), 12385-12414. https://doi.org/10.1021/ acs.chemrev.7b00259

Savjani, K. T., Gajjar, A. K., \& Savjani, J. K. (2012). Drug solubility: importance and enhancement techniques. ISRN pharmaceutics, 2012, 195727. https://doi.org/10.5402/ 2012/195727

WHO (1996). Retrieved from https:/www.who.int/water sanitation_health/resourcesquality/wpcchap2.pdf

Cabral J. P. (2010). Water microbiology. Bacterial pathogens and water. International journal of environmental research and public health, 7(10), 3657-3703. https://doi.org/ 10.3390/ijerph7103657

Guidelines for Drinking-Water Quality: Fourth Edition Incorporating the First Addendum. Geneva: World Health Organization; 2017. 10, Acceptability aspects: Taste, odour and appearance. Retrieved from https://www.ncbi.nlm. nih.gov/books/NBK442378/

Sharma, S. B., Sayyed, R. Z., Trivedi, M. H., \& Gobi, T. A. (2013). Phosphate solubilizing microbes: sustainable approach for managing phosphorus deficiency in agricultural soils. SpringerPlus, 2, 587. https://doi.org/ 10.1186/2193-1801-2-587

Nkansah, M. A., Boadi, N. O., \& Badu, M. (2010). Assessment of the quality of water from hand-dug wells in Ghana. Environmental health insights, 4, 7-12. https://doi.org/ 10.4137/ehi.s3149 